\title{
Analysis of the innovation and development of the socialist market economy theory
}

\author{
Jiayong $\mathrm{Hu}$ \\ Institute of Economics, \\ Chinese Academy of Social Sciences, Beijing, China
}

The socialist

market

economy theory

\begin{abstract}
Purpose - As a major theoretical breakthrough of the Marxist political economy based on the practice of China's reform and opening up, the theory of socialist market economy constitutes an important part of the political economy of socialism with Chinese characteristics. The paper aims to discuss this issue.

Design/methodology/approach - Its essence is that socialism (as a social system) and market economy (as a resource allocation mechanism) can be organically integrated to exert the advantages of both at the same time and generate new institutional and systematic advantages.

Findings - It has condensed many important theoretical viewpoints, involving major theoretical and practical issues, such as the relationship between the government and the market, the basic economic system, the income distribution system, the operation of the market economy and the opening up to the outside world, which have become the basic principles of socialist political economy with Chinese characteristics.

Originality/value - The new practice of comprehensively deepening reform and building a moderately prosperous society in an all-round way is bound to provide an impetus to the deepening and systematization of the theory of socialist market economy.
\end{abstract}

Keywords Development of main theoretical principles,

Political economy of socialism with Chinese characteristics, Socialist market economy theory

Paper type Research paper

The socialist political economy with Chinese characteristics (hereinafter referred to as SPECC), featuring the latest achievement of the Sinicization and modernization of Marxist political economy, constitutes an important component of the theoretical system of socialism with Chinese characteristics. In October 1984, Deng Xiaoping pointed out while appraising the "Decision of the Central Committee of the Communist Party of China on Economic System Reform" that: "the Decision is in itself the first draft of political economy integrating the basic principles of Marxism with the practice of socialism in China" (Deng, 1993). After more than three decades of reform and opening up and economic development practice, SPECC has put forward a series of important theoretical principles and viewpoints and began to form a relatively complete logical structure and ideology. The theory of socialist market economy constitutes an important part of the SPECC. It contains a series of important theoretical principles and viewpoints. The following attempts to outline its development context and elementary contour.

(C) Economic Research Journal. Published in China Political Economy. Published by Emerald Publishing Limited. This article is published under the Creative Commons Attribution (CC BY 4.0) licence. Anyone may reproduce, distribute, translate and create derivative works of this article (for both commercial and non-commercial purposes), subject to full attribution to the original publication and authors. The full terms of this licence may be seen at http://creativecommons.org/licences/by/4.0/ legalcode. Originally published in Simplified Chinese in Economic Research Journal.

The paper is funded by the Research Project of the Great Wall Scholars Project of the Chinese Academy of Social Sciences.

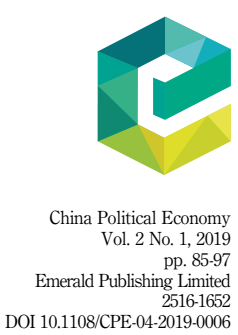


CPE 2,1

\section{The theory of socialist market economy is a major breakthrough in Marxist political economy}

The introduction of the socialist market economy theory (hereinafter referred to as SMET) denotes a major breakthrough made by the political economy with Chinese characteristics to the political economy of Marxism and a major development of scientific socialism.

In the eyes of the classic writers of Marxism, the future society realizes the public ownership of production materials (Marx and Engels 2009b), and "once the society possesses the means of production, merchandise-oriented production will be eliminated forthwith" (Marx and Engels, 2009b). In the future society envisioned by classic writers, "direct social labor" is a very important category. As labor has become "direct social labor," how labor time and means of production are distributed for various purposes "does not require the celebrated 'value' to intervene" (Marx and Engels, 2009b). Before the October Socialist Revolution (1917), Lenin envisaged: "the whole society will become an administrative office" (Lenin, 2009) which implements "direct production and distribution." During the Period of New Economic Policy, Lenin introduced commodity exchanges (different from product exchange) into the Soviet economy, and some important changes have taken place in the views of commodities, currencies, private economy and material interests. However, regarding the relationship between socialism and the commodity economy, Lenin's views have not undergone fundamental changes. He believes that the development of the commodity-currency relationship is only a "gradualist, prudent and devious mode of action" leading to "direct production and distribution" (Lenin, 2009), which is a strategic "retreat." Moreover, in November 1921, Lenin believed that "there are already some signs that can make people see the end of retreat, which can make people see the possibility of stopping this retreat in the near future" (Lenin, 2009). It is precisely because Lenin's fundamental view of the commoditycurrency relationship has not changed that the highly concentrated planned economic system was quickly established in the Soviet Union in the post-Lenin era.

In the mainstream economic thinking of the West, socialism and the market economy have been sharply opposed. Ludwig von Mises' Socialism: An Economic and Sociological Analysis, published in 1922, systematically demonstrated the incompatibility of socialism and market economy. He believes that "it is impossible to sever the market and its price formation mechanism from the functions of society based on the private ownership of the means of production" (von Mises, 2008). This is because public ownership and production factor markets cannot coexist, and it is impossible to form reasonable prices under public ownership, and there is thus no reasonable economic accounting. The choice can only be "Either socialism or a market economy" (2008). Correspondingly, on the issue of ownership, von Mises (1995) also believed that there are only two options that are incompatible with each other: either the public ownership of the means of production or the private ownership of the means of production. Friedrich Hayek also believed that socialism is incompatible with the market economy as without private ownership, it is impossible to have the motivation and information needed for market operation. Although Oskar R. Lange and others refuted the views of Mises and Hayek and believed that the socialist economy could simulate the role of the market and the price mechanism (Lange and Taylor, 1981), they still deemed socialism and market economy as "a dichotomy of two skins."

Since the reform and opening up, a major theoretical contribution of SPECC has been to put forward the theory of socialist market economy (SMET), the essence of which is that socialism as a social system and market economy as a resource allocation mechanism can be organically integrated to exert the advantages of both at the same time and generate new institutional and systematic edges.

The formation of the SMET is a process of continuous breakthrough, enrichment and improvement, along the main line of continuous deepening and scientific understanding of socialism and market economy. The deepening of the understanding of socialism is 
principally reflected in Deng Xiaoping's relevant important theses. In 1985, Deng Xiaoping pointed out that "poverty is not socialism, socialism must eliminate poverty" (Deng, 1993); in the same year, he indicated that "socialism has two very important aspects, one is to take public ownership as the mainstay, and the other is not to polarize" (Deng, 1993). In 1992, Deng Xiaoping pinpointed that "the essence of socialism is to liberate productive forces, develop productive forces, eliminate exploitation, eliminate polarization, and ultimately achieve common prosperity" (Deng, 1993). "If we understand socialism from this new level of practice, jump out of the shackles of traditional ideas, and liberate and develop social productive forces and gradually realize common prosperity as the essence of socialism, then there is no contradiction between socialism and the market economy. Because, from the point of view of liberating and developing social productive forces, the market economy can greatly expand the space for the development of social productive forces by mobilizing the ingenuity of hundreds of millions of people to create and accumulate wealth." General Secretary Xi Jinping (2013) profoundly corroborated this point: "Theories and practices have proved that market allocation of resources is the most efficient form." From the perspective of gradually achieving common prosperity, the market economy, by facilitating capital accumulation and investment and encouraging innovation, can create a steady stream of new jobs to guarantee the opportunities for most people to earn income; meanwhile, by better playing the role of the government, it can build a starting point for fair competition, correct the bias of market competition, and help the disadvantaged and those at risk. Even some economists in the West believe that socialism and market economy are compatible, and some important goals pursued by socialism can be achieved through market mechanisms. For example, McMillan (2006) held that: "The market is not born to run counter to the goals of society."

The deepening of market understanding is a distinctive theoretical feature of SPECC. The Third Plenary Session of the 11th Central Committee of the Communist Party of China, which opened the curtain of China's economic reform and opening up, proposed "focusing on the role of the law of value"; the "Decision of the Central Committee of the Communist Party of China (CPC) on Economic System Reform" adopted by the Third Plenary Session of the 12th CPC Central Committee proposed that the socialist economy is a planned commodity economy on the basis of public ownership; and the report of the 14th CPC National Congress clearly stated that "the goal of economic system reform is to establish a socialist market economic system," wherein "the market plays a fundamental role in resource allocation under the macro-control of socialist countries." "The "fundamental role" of the market is a qualitative leap in the understanding of the market by SPECC, marking the beginning of the formation of the SMET. Under the new historical conditions, the Party Central Committee with Xi Jinping as the general secretary has greatly advanced SPECC's understanding of the market and proposed a new thesis that "the market plays a decisive role in resource allocation, and can better plays the functions of government," thus achieving another qualitative leap in SPECC. This thesis is a scientific summary of the practical experience of China's reform and opening up for nearly four decades. It reflects the successful experience of all countries in the process of seeking economic development and national modernization and will certainly play a crucial role in comprehensively deepening reform and improving the socialist market economic system.

\section{The important principles and viewpoints contained in the SMET}

The SMET has condensed many important theoretical principles and viewpoints, mainly involving major theoretical and practical issues such as the relationship between the government and the market, the basic economic system, the income distribution system, the operation of the market economy and the opening up to the outside world.
The socialist market economy theory 
CPE 2,1

\subsection{The relationship between the government and the market}

The relationship between the government and the market is a long-standing and ever-renewing issue in economics. Be it the development of Marxist political economy or the evolution of Western mainstream economic thinking, one of its important signs is the re-recognition of the relationship between the government and the market and the reorientation of their role. China's reform and opening up is based on a highly centralized planned economic system, it is therefore particularly important to correctly handle the relationship between the government and the market. The report of the 14th National Congress of the Communist Party of China pointed out that the core of determining the objectives of economic restructuring is the "correctly understanding and dealing with the relationship between plans and markets" (Party Literature Research Center of CPC Central Committee, 2011a); the report of the 18th CPC National Congress further pointed out that "the core issue of economic system reform is to handle the government and the market well; and the "Decision" of the Third Plenary Session of the 18th CPC Central Committee reaffirmed this theoretical and practical principle and outlined clear clues for the establishment and improvement of the socialist market economic system.

How to deal with the relationship between the government and the market? From the conscious use of the law of value in the early stage of the reform to the "planned economy as the mainstay supplemented by market regulation" reported in the 12th CPC National Congress, to the "market's fundamental role of resource allocation under the macro-control of socialist countries" reported in the 14th CPC National Congress, and then to the "market playing a decisive role in resource allocation and better playing the role of the government" purported in the Third Plenary Session of the 18th CPC Central Committee have become basic principles of SPECC, due to which our understanding has been pushed forward in depth.

Scientific understanding of the decisive role of the market and how to better play the role of the government is the key to correctly handling the relationship between the government and the market. First of all, we need to conscientiously understand that "it is the general law of the market economy for the market to determine the allocation of resources" (18th CPC National Congress, 2013). The decisive role of the market is manifested in that most economic resources, whether consumer goods (including important consumables) or production factors, including labor, capital, land, technology, information, etc., need to be allocated through market mechanisms to the most efficient sectors and links. The advantage of the market stems from its ability to: synthesize intricate social preferences and transform them into simple price signals (Lange and Taylor, 1981), to guide market players such as enterprises and consumers to make reasonable choices; effectively transmit and utilize countless scattered and hidden knowledge and information to optimize the allocation of resources; make full use of people's internal incentives to drive resources to keep flowing, make the whole economy full of vitality and stamina; and continuously stimulate innovation and entrepreneurship and facilitate organic entities' constant acquisition of new knowledge and elimination of clichés (Phelps, 2013), thereby creating new economies and exploring new productive forces. In short, the advantage of the market economy lies in its ability to mobilize the wisdom and power hidden among millions of people so that all sources of social wealth can flow in full. Of course, the market is not omnipotent, and it is impossible to expand the decisive role of the market and its principles to the public goods, social, political and ethical sectors. "Market design is not an issue of choosing between the market or the government, but an issue that can only be solved by market plus government" (2008). Second, it scientifically defines the role of government, where the allocation of resources is basically handed over to the market, and the government should withdraw from the complicated resource allocation activities and focus on its due diligence. The government 
function is endogenous in the operation law of modern market economy and the institutional regulation of socialism and can be summarized as the construction of four major frameworks: first, the market economy institutional framework, including an ideal rule-of-law order, an effective property rights system, fair and transparent competition rules, and an authoritative regulatory system; second, the overall productivity framework, including large-scale public infrastructure and backbone networks in the sectors of resources, energy, transportation, communications, information, data and ecology, forming the backbone for productivity development and social life; third, the macroeconomic stability framework, which creates a stable market and public life expectation by creating a balanced and stable economic operating environment; and, fourth, the social welfare framework, which prevents social risks and protects basic livelihoods through pension, healthcare, education, unemployment, etc. Of course, in the process of constructing these four frameworks, the government can also introduce and utilize the power of the market to promote resource mobilization and efficiency.

\subsection{Innovation and development of ownership theory}

Ownership constitutes the core of Marxist political economics and is also the core theoretical issue of SPECC. Since the reform and opening up, China's ownership theory has made a series of major breakthroughs, focusing on the deepening and scientific understanding of the public-owned economy, the non-public economy and the relationship between the two, and has had a profound impact on China's reform and opening up process.

In the early stage of reform and opening up, in order to ease employment pressure and activate urban and rural markets, the individual(self-employed) economy was allowed, and then the existence and development of the private economy was allowed, and they were positioned as a supplement to the public ownership economy (POE), while allowing foreign capital to enter to compensate for the funding gap and introduce advanced production and management technologies, thereby opening the prelude to the evolution of China's ownership structure. The 15th CPC National Congress achieved a leap in the theoretical quality of ownership and proposed that "public ownership as the mainstay and co-development of various ownerships" is the basic thesis of the socialist basic economic system. Based on this thesis, some important principles and principles concerning the ownership system in the socialist political economics with Chinese characteristics are proposed, primarily including the mainstay status of public ownership is principally reflected in the dominant position of public assets in the total assets of the society, with the state-owned economy controlling the lifeline of the national economy and playing a leading role in economic development; the form of public ownership realization can and should be subject to diversification, and the shareholding system is a form of capital organization of modern enterprises and can also be used in socialism; establishing a modern enterprise system is the direction of state-owned enterprise reform; and the non-public economy constitutes an important part of China's socialist market economy. In the report of the 16th CPC National Congress, the theory of ownership was further developed. For the first time, the "Two Unwavering" guidelines were put forward, and then they were repeatedly reaffirmed, never wavered and successively formulated a series of policy measures.

Since the 18th CPC National Congress, based on the new historical conditions of comprehensively deepening reform and economic development into the new normal, the theory of ownership has made new developments. The "Decision" of the Third Plenary Session of the 18th CPC Central Committee pointed out that both the public-owned economy and the non-public economy are important components of the socialist market economy and are important foundations for China's economic and social development; the public-owned economic property rights are inviolable and the non-public economic property rights are 
CPE

2,1

equally inviolable; they ensure that all forms of ownership economy use production factors in an equal way, participate in market competition in an open and fair manner, and are equally protected by law; mixed ownership economy is an important form of realization of the basic economic system, improve the state-owned asset management system, reinforce administration by focusing on capital regulation, etc. General Secretary Xi Jinping's (2016, March 4) important speech at the joint conference of the Chinese People's Political Consultative Conference, China Democratic National Construction Association and the All-China Federation of Industry and Commerce systematically elucidated the theoretical and practical principles of China's basic economic system and clarified the vague understanding of the basic economic system, and in particular, the non-public sector of the economy, indicating that "the public and the non-public sector of the economy should be complementary and reciprocal rather than mutually exclusive and counteracting." This speech has consolidated and developed the existing theoretical results. It can be seen that SPECC has formed a relatively clear line of ownership theory and laid a solid foundation for ownership theory for the organic integration of socialism with Chinese characteristics and modern market economy.

Compared with the initial stage of reform and opening up, China's various ownership economies have made considerable progress, and the ownership structure has undergone major changes. The proportion of the POE has declined, but POE's status as the mainstay remains unchanged, still controlling the important industries, key sectors, important links and high-quality assets of the national economy; meanwhile, the proportion of the nonpublic ownership economy (NPOE) in the output value, investment, employment and total tax revenue has soared significantly, and NPOE has, thus, become an important driving force for economic growth and social progress. Meanwhile, China's economic development has stepped into the "new normal" phase, the economic structure has become more complicated, the uncertainty has increased, the importance of innovation has emerged and personalized consumption is building up. It is necessary to further promote the innovation and development of ownership theory under the new historical conditions and lay the corresponding foundation for maintaining high-speed growth of the economy and implementing innovation-driven development strategy.

First is the scientific understanding and maintenance of the dominant position of the public sector of the economy. From the perspectives of output value, employment, taxation and other indicators, the public sector of the economy (POE) no longer has a quantitative advantage, and people are, therefore, worried about the dominant position of public ownership. In a certain sense, this provides a historical opportunity for us to scientifically understand the dominant position of public ownership. We need to scientifically grasp the dominant position of public ownership from the inherent stipulation of socialism with Chinese characteristics and the inherent law of modern market economy, to keep abreast of the times. The dominant position of public ownership requires a quantitative prescriptiveness[1], but, more importantly, the qualitative prescriptiveness, that is, the dominant position of public ownership, should be principally embodied in the POE, especially the basic framework of the state-owned economy that constitutes the national economy and social welfare. Specifically, the state-owned economy and state-owned capital are primarily distributed in important industries, key sectors and important links that are related to national security, the lifeline of the national economy and the basic livelihood of the people. They form the backbone of economic and social development, and then, through the penetration, enlargement and influence mechanism of the market economy, they have become the "general illumination" covering the entire economic and social life (Marx and Engels, 2004).

Second, scientific understanding of the non-public economy constitutes an important part of the development of modern productive forces. The rapid development of science 
and technology can no longer regard the non-public economy and small- and mediumsized enterprises as backward productivity[2]. In the era of large-scale mechanized industry, the expansion of production scale often constitutes the basis of the development of productivity, whereas the trend of modern productivity no longer develops along the unitary direction of large-scale production, but diversified direction of large-, medium- and small-scale production. Flexible use of modern technologies can be practiced, and smalland medium-sized enterprises, and even micro-enterprises, can be a form of enterprise organization that accommodates and utilizes modern productivity. What is more, SMEs have even become an important source of innovation. There is a need to understand the reasons for the existence of the non-public economy based on "diversity," which is the basic condition for adapting to economic complexity, overcoming uncertainty, stimulating innovation and quenching individual needs. The modern economy relies on the diversity of society to achieve prosperity. Economic vitality also depends on the diversity of entrepreneurs (Phelps, 2013) because a society's willingness and prowess to innovate and are closely related to diversity of financiers, entrepreneurs, producers, consumers, corporate organizational forms and the forms of social property, which determine the vitality and creativity of a society.

Third is further understanding of the important role of the mixed ownership economy. The mixed ownership economy with cross-shareholding and mutual integration of various capitals will become the bedrock of China's economic operation, and the shareholding system is an important form of existence of mixed ownership economy. Scientific understanding of the nature of the shareholding system is very important for promoting the development of a mixed ownership economy. The discussion of share capital by Marx and Engels in the past can give us important theoretical enlightenment. Marx believes that the capital of a joint stock company "directly takes the form of social capital (i.e. the capital of those individuals directly united) and is opposed to private capital" (Marx and Engels, 2009e); Engels points out that "capitalist production operated by a joint stock company is no longer a private production, but a production under the care of many" (Marx and Engels, 2009c). Marx and Engels still believe that the share capital of capitalism has the nature of "social capital" and "co-production." Then, in the socialist market economy with public ownership as the mainstay, the share capital will inevitably, to a greater extent, reflect the nature of "social capital" and "co-production" and become the realization form of the dominant position of public ownership or integrate with the entities of public ownership.

\subsection{Innovation and development of income distribution theory}

The SPECC has formed a series of important theoretical principles concerning income distribution, involving many aspects such as a personal income distribution system, distribution according to production factors, fairness-efficiency relationship and common prosperity.

Establishing an income distribution system of the primary stage of socialism with "performance-based distribution as the mainstay that coexists with multiple modes of distribution" is a major breakthrough in the distribution theory of Marxist political economics, embodying the essential prescriptiveness of socialism and the operating laws of modern market economy. In the early days of reform and opening up, in order to overcome egalitarianism and emphasize the principle of performance-based distribution, the 13th CPC National Congress proposed to "implement a variety of distribution models with performance-based distribution as the mainstay." The Third Plenary Session of the 14th Central Committee clearly proffered the income distribution system with "performancebased distribution as the mainstay that coexists with multiple modes of distribution" (Party Literature Research Center of CPC Central Committee, 2011b), thus achieving a qualitative leap in the theory and system of income distribution. In the subsequent development, under the premise of insisting on performance-based distribution, the connotation of various 
CPE

2,1

92

distribution methods was gradually clarified, and the production-factor-based distribution was introduced. The report of the 15th CPC National Congress proposed to integrate the performance-based distribution with the production-factor-based distribution, "allowing and encouraging capital, technology and other production factors to partake in the distribution of income." The report of the 16th CPC National Congress put forward the "establishment of principles for production factors such as labor, capital, technology and management to partake in the distribution of income commensurate with their contributions." The Third Plenary Session of the 18th CPC Central Committee proposed "a sound income distribution mechanism determined by factor markets such as capital, knowledge, technology, and management." Allowing production factors to participate in the distribution, the residents' income channels are diversified, and the snowballing non-labor income such as property income has provided a strong impetus for the operation of the market mechanism.

The system of "performance-based distribution as the mainstay that coexists with multiple modes of distribution" is intrinsically consistent with the basic economic system with the "public ownership as the mainstay and co-development of multiple ownership economic entities" and in line with the general principle of income distribution in Marxist political economy, that is, "any kind of distribution of the means of consumption is nothing more than the result of the distribution of production conditions itself" (Marx and Engels, 2009d); it stimulates the enthusiasm of hundreds of millions of people to create wealth, earn income and improve their economic status, driving the constant flow and relocation of production factors such as labor, capital, land, technology and information, thus laying the foundation for the distribution system that is compatible with the operation of the socialist market economy.

For the theory and system of income distribution needs to be further optimized, an important aspect is to deal with the relationship between fairness and efficiency under new historical conditions. Before 2003, our principle of dealing with the equity-efficiency relationship was "giving priority to efficiency with due consideration to fairness[3]," which is closely related to the status of "equalitarian Big-Pot ("everybody eating from the same big pot"-equalitarian treatment of enterprises and individuals regardless of their performances)" and a dearth of economic inefficiency and vitality in the initial reform of China's distribution system. Since 2004, especially since the 18th CPC National Congress, the principle of dealing with the equity-efficiency relationship has undergone important changes, including "more emphasis on social equity," "the focus on raising the income level of low-income earners," "a gradual expansion of the proportion of middle-income earners," enabling all the people to have more "sense of gain," etc. At the same time, the understanding of "equity (fairness)" comes closer to its essence. The Report of the 18th CPC National Congress regards the equity of "rights, opportunities, and rules" as the mainstay of social equity. This "equity" concept is not only consistent with the essential provisions of socialism, but also with the inherent laws of the modern market economy, thus laying the foundation for establishing the scientific equity-efficiency relationship.

From the perspective of the whole process of achieving equity, the three elements, in proper order, namely, equity of starting point, equity of process and equity of results, also influence each other. In the modern market economy, given an equal starting point and equal process, the resulting competitive outcome can be considered to be in line with the principle of fairness, and people will recognize and accept this result to a large extent (Buchanan, 1989). Therefore, equity of starting point and equity of process stay at the core of the process of building a fair society. However, this result may include the difference in income and wealth caused by fair competition itself, and this is just where the driving force of economic development lies. The result of fairness needs to be grasped from two aspects: on one hand, the starting point and process forming the results must be fair, 
otherwise the results they bring will not be recognized by society; on the other hand, the income and wealth gap from such results should not be too disparate and should not cause polarization. Equity of results has, in addition to its own value gained from relying on the equity of starting point and process, its own independent value. This is because of the following: first, the fairness of the outcome (equity of results) will then affect the equity of the new starting point and the new process. Specifically, the competition results of the previous round or the previous generation often constitute the conditions for competition of the next round or next generation, thus determining the starting point of a new round of competition and the ability to use opportunities. Second, relative equal income and wealth distribution are more conducive to the smooth progress of social reproduction, in particular, the counteraction of consumption (especially that of low- and middle-income groups) on production and the reproduction of labor, affecting the free and comprehensive development of human beings and the liberation of human nature. However, there is a limit to the act of correcting the outcome of fair competition, that is, it shall not undermine the prime power driving economic development and market operations. Therefore, in the pursuit of equity, the first task is to establish the conditions and environment for fair competition, to fully mobilize the potential of people to create wealth and then appropriately correct the results of competition, to control the gap between income and wealth in the society in an acceptable range.

Equity of rights, equity of opportunities and equity of rules are the keys to achieving fairness in the starting point, fairness in the process, and fair outcomes. In order to achieve social equity and promote economic efficiency, we must first ensure the fairness of the starting point and the fairness of the process. For the fairness of the starting point, we must ensure that all sectors of society, especially those of low-income families, have access to fair education. For the government, education policy is the most reliable way to make the country embark on a more equal path of distribution. Education is and will always be a major way out for poor families and children to escape poverty (Meier and Stiglitz, 2003). The nutritional status, labor health status and family living conditions of children in low-income families will also have an important impact on the fairness of the starting point. For process equity, competition rules are required to be fair and transparent, and competition opportunities open. People shall have the freedom to migrate, choose jobs, invest and trade and have the right to equal access to, and use of, production factors. Therefore, opening up the household registration system, eliminating various barriers to entry and exit, developing financial markets, improving information infrastructure, etc., are all important factors in improving process equity. If we achieved starting point equity and process equity, we will be able to achieve socially acceptable outcomes to a greater extent. Based on this, the competition results can be appropriately corrected through measures such as social security, subsidies for low-income groups and poverty alleviation to achieve a higher degree of fairness in outcome. Furthermore, in order to alleviate the consumption gap caused by income gap and wealth gap, we also need to improve the property rights protection system and develop financial markets to encourage wealthy groups to convert most of their income and wealth into investment in the reproduction process. While augmenting the employment and income opportunities for low-income groups, the gap between the actual consumption of social members, as well as the consumption gap caused by the income gap and the wealth gap, will be narrowed, to achieve a higher degree of equity for consumption and welfare.

\section{Theory of socialist economic operation}

In the socialist market economy, the distribution of labor time and the allocation of production factors are mainly achieved through the role of the law of value, which also greatly affects the distribution of personal income (see footnote 2). Therefore, the SPECC 
CPE 2,1

must study the law of the operation of the market economy. When analyzing it, Marx discussed the general principles of market economy operation and provided theoretical inspiration for us to analyze the operation of the socialist market economy. For example, Marx believed that pro rata (proportional) distribution of social labor is a "natural law," and this law works through the law of value under the conditions of commodity economy, which has intrinsic consistency in theory with the "decisive role of the market in resource allocation" proposed by China. Marx emphasizes the importance of ownership, freedom and equality in commodity exchange. He believes that "from the exchange itself, individuals and each individual are themselves reflected as an exclusive and dominant (with a decisive role) entity in commodity exchange. Thus, this establishes the complete freedom of the individual: a voluntary transaction; neither party uses violence, which is "in an equal relationship," "in addition to the provisions of equality, it is also subject to the provisions of freedom” (Marx and Engels, 1979).

SPECC has many important expositions on economic operations. First, the cultivation of a complete market system is emphasized. Marx pointed out: "The market [...] takes the overall form" (Marx and Engels, 1979). Only a complete market system suffices to support the market to play a decisive role in resource allocation. The completeness of the market system means not only that the various markets are complete and well-developed, but also that they are in an organic connection, interaction and tending to general equilibrium. In 1993, the "Decision of the Central Committee of the Communist Party of China on Several Issues Pertaining to the Establishment of a Socialist Market Economic System" proposed to focus on cultivating financial markets, labor markets, real estate markets, technology markets and information markets. In 2003, the "Decision of the CPC Central Committee on Several Issues Pertaining to the Improvement of a Socialist Market Economic System" proposes to develop the futures market. To date, various markets have been existent, and many resources are allocated through the market. Second, the unity, openness and orderly competition of the market system are emphasized. Open up opportunities to market players, endow them with the right to free choice and fair competition, and, at the same time, let them bear the risk of decision making and harden budget constraints; Market rules are open and transparent, and goods and elements can flow freely. Third, implementing effective market supervision. Supervision is the most important microeconomic function of the government to maintain market competition order, eliminate monopoly and ensure the safety of food, medicine, environment and production sites.

The free flow of production factors is the precondition for the law of value, law of supply and demand, and law of competition. A future focus of modern market system construction is to improve the production factor market and enhance the liquidity of elements to stimulate the endogenous power of the market economy. Referring to the averaging of profits, that is, the dynamic process of resource allocation, Marx emphasizes the importance of the following two conditions: First, "Capital has greater activity, that is, it is easier to transfer from one department/place to another." Second, "labor has more mobility of moving more quickly from one department/place to another." This requires: "a full freedom of trade within the society, eliminating all monopolies other than natural monopoly," and "abolishing any law that prevents workers from moving from one production sector to another, or from one production location to another" (Marx and Engels, 2009c). These classic discourses provide important inspiration for the study of the theory of market economy operation in SPECC.

\section{The theory of opening up to the outside world}

In the political economic system envisioned by Marx, be it the "five-chapter structural plan" or the "six-volume structural plan," they invariably contain the contents of international economic relations such as international trade and international market, indicating that the 
classic writers were already fully aware of the importance of the internationalization of productivity, resource allocation and interest distribution. Marx believes that the international division of labor is the basis for international trade and international flow of capital, which, in turn, strongly promote the international division of labor to a broader, deeper and higher level. Referring to the role of international trade and the international market, Marx pointed out that the world market "prepares ready for civilization and progress everywhere, so that everything that happens in all civilized countries will inevitably affect the rest of the world" (Marx and Engels, 1958); "New world market relationships also cause the exquisiteness and variety of products" (Marx and Engels, 2009f). The law of value also plays an important role in the international market, regulating the distribution of the benefits generated by the internationalization of production among different countries. Among them, countries with advanced technology, high labor complexity and high labor productivity occupy a large share of interests. Thus, "three working days in one country may also be exchanged with one working day in another" (Marx and Engels, 1974). Marx also understood the nature of economic internationalization from the perspective of production relations. He said: "The trend of creating world markets has been directly contained in the concept of capital itself" (Marx and Engels, 1979). A basic principle of Marxist political economy is to grasp the nature of economic globalization from the two aspects of productivity and production relations, which also applies to SPECC.

Since the second half of the twentieth century, the international division of labor has developed rapidly. Not only have the traditional inter-industry division of labor and interproduct specialization deepened, but the intra-industry division of labor and intra-product specialization have also emerged and deepened. The industrial chain has become longer and longer, and labor productivity higher and higher. At the same time, transportation, communications and information technology are developing rapidly. Under the combined effect of these factors, the international flow of products, services and production factors is expanding day by day with faster speed. Production, exchange, distribution and consumption are becoming more and more cosmopolitan. Actively participating in the international division of labor, occupying a favorable position in the international division of labor chain and the formulating international economic rules constitute an inevitable choice for countries to seek competitive advantage and economic development.

Based on the background of economic globalization and China's practice of reform and opening up, SPECC has gradually formed a series of theoretical views on opening up to the outside world. It believes that opening up is a long-term basic national policy that aims to make full use of both domestic and international markets and resources, combine "bringing in" and "going out," actively participate in international competition and international economic cooperation, play a key role in China's comparative advantages, establish an open, safe and efficient economy with mutual benefit and multi-balance, actively participate in global governance, etc. The main policy proposals include the gradual deep integration into the global division of labor system through the establishment of special economic zones and all-round opening, foreign direct investment and outward foreign direct investment, accession to international organizations such as the World Trade Organization, implementation of the "Belt and Road" strategy, promotion of international production capacity cooperation, etc.

The theory of opening up awaits, nonetheless, to explore a series of important theoretical and practical issues: first, under the conditions of new technology, the rules of international division of labor and industrial evolution, and how to improve China's position in the international division of labor and interest chain, to achieve static and dynamic comparative advantages; second, the role of the law of value in the international market and how to promote a reasonable share of global interest distribution through industrial upgrading and innovation; and, third, the ways to participate in global governance. Compared with the 
domestic market, the world market is more volatile, where the State plays an important role, the mobility of production factors is low, there are many barriers and the capital threshold is high. Therefore, the importance of the formulation of rules for competition and participation looms large. SPECC is able to accomplish much on such issues.

\section{Notes}

1. It should be noted that this quantitative prescriptiveness is not a priori, but changes with practice, and is comprehensively determined by the prescriptiveness of the socialist system with Chinese characteristics, the stage of economic development, the decisive role of market allocation resources, the inherent operation of the market and other factors.

2. The Political Economy textbook and some related papers generally link them to the backwardness of productivity and the imbalance of economic development when analyzing the reasons for the existence of the non-public economy and SMEs. This view needs to change with the development of modern productivity.

3. Under the conditions of market economy, the "performance" in performance-based distribution is measured by the amount of value formed by it: whether labor is invested in effective use, and whether value can be formed is also confirmed by the law of value. As for the production-factorbased distribution, it is basically regulated by the law of value, the law of supply and demand, and the law of competition.

\section{References}

18th CPC National Congress (2013), Decision of the Central Committee of the Communist Party of China on Some Major Issues Concerning Comprehensively Deepening the Reform, People's Publishing House, p. 5.

Buchanan, J.M. (1989), Liberty, Market and State: Political Economy and the 1980s (Chinese translation), Shanghai Joint Publishing Company, p. 197.

Deng, X. (1993), Selected Works of Deng Xiaoping, People's Publishing House, p. 138.

Lange, O.R. and Taylor, F.M. (1981), On the Economic Theory of Socialism, China Social Sciences Press, pp. 9-23.

Lenin (2009), Lenin's Monographs (on Socialism), People's Publishing House, p. 41.

McMillan, J. (2006), Reinventing the Bazaar: A Natural History of Markets, Chinese Translation, CITIC Publishing House, p. 228.

Marx, K.H. and Engels, F.V. (1958), Marx and Engels Anthology, People's Publishing House, pp. 361-362.

Marx, K.H. and Engels, F.V. (1974), The Complete Works of Marx and Engels, People's Publishing House, p. 112.

Marx, K.H. and Engels, F.V. (1979), The Complete Works of Marx and Engels, People's Publishing House, p. 391.

Marx, K.H. and Engels, F.V. (2004), Marx and Engels Collection, People's Publishing House, p. 31.

Marx, K.H. and Engels, F.V. (2009a), Marx and Engels Anthology, People's Publishing House, pp. 218-219.

Marx, K.H. and Engels, F.V. (2009b), Marx and Engels Anthology, People's Publishing House, p. 287.

Marx, K.H. and Engels, F.V. (2009c), Marx and Engels Anthology, People's Publishing House, p. 410.

Marx, K.H. and Engels, F.V. (2009d), Marx and Engels Anthology, People's Publishing House, p. 436.

Marx, K.H. and Engels, F.V. (2009e), Marx and Engels Collection, People's Publishing House, pp. 494-495.

Marx, K.H. and Engels, F.V. (2009f), Marx and Engels Anthology, People's Publishing House, p. 512. 
Meier, G.M. and Stiglitz, J. (2003), Frontiers of Development Economics: The Future in Perspective (Chinese Translation), China Financial and Economic Publishing House, p. 390.

Party Literature Research Center of CPC Central Committee (2011a), Selected Works of Important Documents Since the Fourteenth CPC National Congress (I), Central Party Literature Press, p. 15.

Party Literature Research Center of CPC Central Committee (2011b), Selected Works of Important Documents since the Fourteenth National Congress (I), Central Party Literature Press, pp. $452-476$.

Phelps, E. (2013), Mass Flourishing: How Grassroots Innovation Created Jobs, Challenge, and Change, Chinese Translation, CITIC Press, p. 41.

von Mises, L. (1995), The Free and Prosperous Commonwealth: An Exposition of the Ideas of Classical Liberalism, China Social Sciences Press, p. 118.

von Mises, L. (2008), Socialism: An Economic and Sociological Analysis (Chinese Translation), China Social Sciences Press, p. 103.

Xi, J. (2013), "Explanatory notes for the 'decision of the central committee of the communist party of china on some major issues concerning comprehensively deepening the reform”, People's Daily, November 16, available at: http://politics.people.com.cn/n/2013/1116/c1024-23560847.html

$\mathrm{Xi}, \mathrm{J}$. (2016), "Unswervingly adhere to China's basic economic system and promote the healthy development of various ownership economy”, People's Daily, March 9, available at: http://theory. people.com.cn/n1/2018/0103/c416126-29743056.html

\section{Corresponding author}

Jiayong Hu can be contacted at: jyhu@cass.org.cn
The socialist market economy theory 